\title{
Pengaruh Pendidikan Kesehatan tentang Covid-19 Melalui Media Audio Visual terhadap Pengetahuan Remaja di Madrasah Aliyah Nurul Huda Kota Depok Tahun 2020
}

\author{
Marwiyatu Ramadania, Agustina, Dwi Mutia Wenny \\ Program Studi Kesehatan Masyarakat Program Sarjana, Fakultas Ilmu Kesehatan \\ Email: marwiaturamadhania@gmail.com
}

\begin{abstract}
Abstrak
Latar Belakang: Tim SATGAS COVID-19 mencatat pada 13 Desember 2020 sebanyak 54.368 remaja yang terkonfirmasi positif COVID-19. Hal ini diakibatkan dari kurangnya pengetahuan remaja tentang COVID-19. Untuk meningkatkan pengetahuan pada remaja salah satunya melalui pendidikan kesehatan. Tujuan penelitian ini untuk mengetahui pengaruh penyuluhan kesehatan tentang COVID-19 melalui media audio-visual terhadap pengetahuan remaja.

Metode: Jenis penelitian kuantitatif dengan metode penelitian pre-eksperimental. Populasi penelitian ini yaitu seluruh siswa-siswi Madrasah Aliyah Nurul Huda Kota Depok. Sampel yang digunakan sejumlah 60 responden. Teknik pengambilan sampel dengan sampling jenuh. Analisis data menggunakan analisa Univariat dan Bivariat menggunakan uji Wilcoxon Signed Ranks Test.

Hasil: Hasil penelitian menunjukkan sesudah dilakukan pendidikan kesehatan melalui media audio-visual ratarata tingkat pengetahuan remaja meningkat dari 12,52 menjadi 20,97. P-value yang diperoleh sebesar $0,001<0,05$. Pendidikan kesehatan tentang COVID-19 melalui media audio-visual memberikan pengaruh positif terhadap pengetahuan remaja.

Kesimpulan: Terdapat peningkatan yang signifikan pada pengetahuan remaja sesudah dilakukan pendidikan kesehatan. Diharapkan agar remaja dapat mencari informasi mengenai COVID-19 dari berbagai sumber yang dapat diakses dengan mudah dan remaja memiliki kemauan untuk memahami lebih dalam mengenai COVID-19 agar remaja dapat melakukan upaya pencegahan penyebaran COVID-19 dengan baik.
\end{abstract}

Kata Kunci: Pengetahuan, Pendidikan Kesehatan, Media Audio-visual, Remaja, COVID-19

\section{The Effect of Health Education about Covid-19 Through Audio Visual Media on Adolescent Knowledge in Madrasah Aliyah Nurul Huda, Depok City in 2020}

\begin{abstract}
Background: The COVID-19 Task Force Team noted that on December 13, 2020, 54,368 teenagers were confirmed positive for COVID-19. This is due to the lack of knowledge of teenagers about COVID-19. One of the ways to increase knowledge in adolescents is through health education. The purpose of this study was to determine the effect of health education on COVID-19 through audio-visual media on adolescent knowledge.

Method: This type of quantitative research with pre-experimental research methods. The population of this research is all students of Madrasah Aliyah Nurul Huda Depok City. The sample used was 60 respondents. The sampling technique was saturated sampling. Data analysis used Univariate and Bivariate analysis using the Wilcoxon Signed Ranks Test.

Results: The results showed that after health education was conducted through audio-visual media, the average level of knowledge of adolescents increased from 12.52 to 20.97. The p-value obtained is 0.001<0.05. Health education about COVID-19 through audio-visual media has a positive influence on adolescent knowledge.

Conclusion: There is a significant increase in adolescents knowledge after health education. It is hoped that adolescents can seek information about COVID-19 from various sources that can be accessed easily and teenagers have the willingness to understand more deeply about COVID-19 so that adolescents can make efforts to prevent the spread of COVID-19 properly.
\end{abstract}

Keywords: Knowledge, Health Education, Audio-visual Media, Adolescents, COVID-19

Korespondensi: Marwiyatu Ramadania

Email: marwiaturamadhania@gmail.com 


\section{PENDAHULUAN}

Remaja adalah usia 10-19 tahun yang sedang mengalami pertumbuhan dan perkembangan yang sangat cepat, baik secara biologis, kognitif dan sosial-emosional yang dapat berpengaruh pada kesehatan ${ }^{1}$. Salah satu perubahan kognitif ialah tingkat pengetahuan remaja. Pertumbuhan dan perkembangan secara fisik dan mental yang belum berkembang dengan baik mengakibatkan kurangnya pengetahuan pada remaja, serta informasi yang kurang dari keluarga ${ }^{2}$. Tindakan yang terwujud pada seseorang dapat disebabkan oleh pengetahuan yang dimilikinya. Suatu informasi yang diberikan pada individu akan memiliki pengaruh pada pengetahuannya ${ }^{3}$. Saat ini COVID-19 (Coronavirus Deseases 2019) merupakan permasalahan kesehatan yang menjadi perhatian dunia dengan jumlah kasus yang mengalami peningkatan setiap harinya yang menyerang segala usia termasuk usia remaja ${ }^{4}$. Hal ini berdasarkan catatan Tim SATGAS COVID-19 pada tanggal 13 Desember 2020 penderita positif COVID-19 pada umur 6-18 tahun sebanyak 54.368 remaja yang terkonfirmasi positif dan sebanyak 376 remaja yang meninggal dunia di Indonesia akibat COVID195. Penyebab penularan COVID-19 pada remaja salah satunya adalah pelanggaran terhadap protokol kesehatan. Berdasarkan catatan Satpol PP Yogyakarta saat melakukan gelar operasi razia protokol kesehatan pada bulan agustus 2020 terdapat 5.924 masyarakat yang sebagian besarnya berusia remaja melakukan pelanggaran protokol kesehatan dengan tidak menggunakan masker pada saat keramaian ${ }^{6}$.

Suatu permasalahan kesehatan terjadi akibat dari kurang pengetahuan terhadap suatu penyakit. Berdasarkan penelitian yang dilakukan oleh Dana Riksa pada tahun 2020 menunjukkan bahwa jumlah masyarakat Indonesia yang tidak mematuhi peraturan dari pemerintah dalam mengatasi wabah nya COVID-19 masih sangat tinggi hal ini disebabkan karena adanya bias kognitif ${ }^{7}$. Usia merupakan salah satu faktor yang memberikan pengaruh pada pengetahuan seseorang, semakin bertambahnya usia, maka semakin matang aspek biologis dan psikologis sehingga semakin dewasa seseorang. Semakin dewasa seseorang tersebut maka semakin meningkat pengetahuan yang diperolehnya ${ }^{8}$. Berdasarkan survei yang dilakukan oleh UNICEF pada
4000 remaja mengenai COVID-19 membuktikan bahwa masih terdapat $25 \%$ remaja yang tidak mengetahui sama sekali mengenai COVID-19. Selain itu, ada yang mengetahui gejala COVID-19, tetapi belum mengetahui cara pencegahan dari penyakit ini ${ }^{9}$. Masalah ini dapat terjadi dikarenakan rendahnya kemampuan mencari sumber informasi serta tidak mempunyai akses pada media informasi sehingga remaja mempunyai pengetahuan yang rendah atas mewabahnya COVID-19 ini. Sejalan pada teori efek Dunning-Kruger bahwa seseorang yang mempunyai pengetahuan yang cukup dan referensi sumber informasi yang baik maka dapat lebih mudah untuk patuh dan menjalankan anjuran dari pemerintah ${ }^{7}$.

Oleh karena itu, pengetahuan mengenai COVID-19 yang baik perlu dimiliki oleh semua kalangan masyarakat termasuk usia remaja untuk dapat mengatasi permasalahan kesehatan ini. Berdasarkan permasalahan yang terjadi, maka perlu dilakukan upaya pencegahan COVID-19 melalui peningkatan pengetahuan tentang COVID-19 yang baik sehingga remaja memiliki kemauan dan kesadaran dalam upaya pencegahan COVID19. Salah satu cara meningkatkan pengetahuan seseorang adalah melalui pendidikan kesehatan. Oleh karena itu, peneliti akan melakukan penelitian mengenai pengaruh pendidikan kesehatan tentang COVID-19 terhadap pengetahuan remaja untuk membuktikkan apakah melalui pendidikan kesehatan dapat meningkatkan pengetahuan remaja atau tidak. Pendidikan kesehatan tentang COVID-19 dilakukan menggunakan media pendidikan yaitu media audio-visual. Media audio-visual memberikan dampak yang sangat besar dalam peningkatan pengetahuan pada remaja, hal dikarenakan media audio-visual memberikan stimulus pada pendengaran dan penglihatan, sehingga hasil yang didapatkan lebih baik ${ }^{10}$. Sekolah yang dipilih untuk dilakukan penelitian pengaruh pendidikan kesehatan tentang COVID-19 terhadap pengetahuan remaja yaitu Madrasah Aliyah Nurul Huda Kota Depok. Sekolah ini dipilih karena berdasarkan survei awal yang dilakukan melalui wawancara pada siswa-siswi Madrasah Aliyah Nurul Huda Kota Depok terdapat lima dari lima anak belum mengetahui tentang COVID-19 dengan baik sehingga penting dilakukan pendidikan kesehatan tentang 
COVID-19 pada remaja agar dapat mendorong upaya pencegahan penyebaran COVID-19.

\section{METODE}

Penelitian ini merupakan penelitian kuantitatif. Penelitian dilakukan di Madrasah Aliyah Nurul Huda Kota Depok. Penelitilan ini berlangsung sejak bulan November 2020 hingga Januari 2021. Populasi dalam penelitian ini adalah siswa-siswi kelas X, XI, dan XII di Madrasah Aliyah Nurul Huda. Dalam penelitian ini, teknik pengambilan sampel menggunakan sampling jenuh dengan jumlah sampel sebanyak 60 orang. Data yang digunakan dalam penelitian ini adalah data primer dan data sekunder.

Data primer diperoleh dengan menggunakan kuesioner (lembar pre-test dan post-test) melalui google form. Data primer ini berisi tentang karakteristik ayah dan ibu responden, karakteristik responden, dan 25 pertanyaan pengetahuan mengenai COVID-19.

Pengolahan data dilakukan dengan editing, coding, entry, dan cleaning. Setelah itu, data diolah untuk mendapatkan hasil analisis univariat dan bivariat menggunakan Uji Wilcoxon Signed Rank Test dikarenakan data tidak bersdistribusi normal dengan salah satu aplikasi program analisis data.

\section{HASIL}

\section{Tabel 1 Distribusi Karakteristik Responden} (Usia, Jenis Kelamin)

\begin{tabular}{lcc}
\hline \multicolumn{1}{c}{$\begin{array}{c}\text { Karakteristik } \\
\text { Responden }\end{array}$} & n & Persentase (\%) \\
\hline Usia Responden & & \\
14-15 tahun & 12 & 20 \\
16-17 tahun & 36 & 60 \\
18-19 tahun & 12 & 20 \\
Jenis Kelamin & & \\
Perempuan & 32 & 53,3 \\
Laki-laki & 28 & 46,7 \\
\hline
\end{tabular}

Gambaran karakteristik responden (siswa-siswi) di Madrasah Aliyah Nurul Huda Kota Depok didapatkan bahwa dari total 60 responden, usia responden paling banyak berada pada kategori usia 16-17 tahun yaitu sebesar $60 \%$ (36 orang). Begitu juga distribusi jenis kelamin paling banyak terdapat pada kategori perempuan yaitu sebesar 53,3\% (32 orang).
Tabel 2 Distribusi Tingkat Pengetahuan Responden Tentang COVID 19

\begin{tabular}{lcccc}
\hline \multicolumn{1}{c}{ Tingkat } & \multicolumn{2}{c}{ Pre-test } & \multicolumn{2}{c}{ Post-test } \\
\cline { 2 - 5 } Pengetahuan & $\mathbf{n}$ & $\mathbf{\%}$ & $\mathbf{n}$ & $\mathbf{\%}$ \\
\cline { 2 - 5 } Kurang & 43 & 71,7 & 0 & 0 \\
Cukup & 16 & 26,7 & 11 & 18,3 \\
Baik & 1 & 1,7 & 49 & 81,7 \\
\hline \multicolumn{1}{c}{$\quad$ Total } & 60 & 100 & 60 & 100 \\
\hline
\end{tabular}

Distribusi tingkat pengetahuan remaja siswa-siswi di Madrasah Aliyah Nurul Huda Kota Depok mengenai COVID-19, sebelum dilakukan pendidikan kesehatan yaitu yang berada pada kategori kurang menunjukkan presentase yang cukup tinggi sebesar $71,7 \%$ (43 orang), kategori cukup sebesar 26,7\% (16 orang) dan kategori baik sebesar 1,7\% (1 orang). Namun sesudah dilakukan pendidikan kesehatan melalui media audio-visual berupa video, pengetahuan remaja mengalami peningkatan sehingga yang berada pada kategori pengetahuan kurang menurun menjadi $0 \%$ ( 0 orang), kategori cukup menurun sedikit menjadi $18,3 \%$ (11 orang) dan kategori baik meningkat menjadi $81,7 \%$ (49 orang).

\section{Tabel 3 Distribusi Rata-rata Pengetahuan} Responden Tentang COVID-19

\begin{tabular}{lcccc}
\hline \multicolumn{1}{c}{ Variabel } & Mean & SD & Min & Max \\
\hline $\begin{array}{l}\text { Pengetahuan tentang COVID-19 } \\
\begin{array}{l}\text { Pre-test } \\
\text { (Sebelum) }\end{array}\end{array}$ & 12,52 & 2,340 & 9 & 20 \\
$\begin{array}{l}\text { Post-test } \\
\text { (Sesudah) }\end{array}$ & 20,97 & 2,025 & 16 & 25 \\
\hline
\end{tabular}

Adapun distribusi rata-rata pengetahuan remaja siswa-siswi kelas X, XI, dan XII Madrasah Aliyah Nurul Huda Kota Depok mengenai COVID-19 sebelum dan sesudah pendidikan kesehatan didapatkan bahwa ratarata nilai pre-test adalah 12,52 dengan standar deviasi sebesar 2,340, sedangkan nilai post-test mengalami peningkatan rata-rata menjadi 20,97 dengan standar deviasi sebesar 2,025. Nilai pengetahuan terendah pada pre-test yaitu 9 dan tertinggi yaitu 20. Sedangkan nilai pengetahuan terendah pada post-test yaitu 16 dan tertinggi yaitu 25. Penilaian diambil berdasarkan jumlah soal yang benar dari jumlah soal sebanyak 25 soal. 
Tabel 4 Hasil Uji Wilcoxon

\begin{tabular}{clcccc}
\hline & & n & $\begin{array}{c}\text { Mean } \\
\text { Rank }\end{array}$ & $\begin{array}{c}\text { Sum Of } \\
\text { Ranks }\end{array}$ & $\begin{array}{c}p- \\
\text { Value }\end{array}$ \\
\hline $\begin{array}{c}\text { Pre- } \\
\text { test- }\end{array}$ & $\begin{array}{l}\text { Negative } \\
\text { Ranks }\end{array}$ & 0 & 0,00 & 0,00 & \\
$\begin{array}{c}\text { Post- } \\
\text { test }\end{array}$ & $\begin{array}{l}\text { Positive } \\
\text { Ranks }\end{array}$ & 60 & 30,50 & 1830,00 & 0,001 \\
& & & & \\
& Ties & 0 & & & \\
\hline
\end{tabular}

Perbandingan skor sebelum dan sesudah dilakukan pendidikan kesehatan menunjukan jumlah negative rank yaitu 0, dapat diartikan bahwa tidak ada skor pre-test yang lebih besar dari skor post-test. Sedangkan positive rank sebesar 60, diartikan bahwa semua data yang ada memiliki skor pre-test lebih kecil dari skor post-test. Ties adalah nilai pre-test dan posttest memiliki kesamaan, didapatkan hasil sebanyak 0 sehingga dinyatakan tidak ada nilai pre-test dan post-test yang memiliki kesamaan. Adapun Nilai signifikansi (p-value) yang diperoleh sebesar 0,001 . Hal ini berarti p-value $<0,05(\alpha=5 \%)$, maka dapat disimpulkan bahwa ada pengaruh pendidikan tentang COVID-19 melalui media audio-visual berupa video terhadap pengetahuan remaja di Madrasah Aliyah Nurul Huda Kota Depok.

\section{PEMBAHASAN}

\section{Karakteristik Responden}

Responden pada penelitian ini berjumlah 60 siswa-siswi kelas X, XI, dan XII pada salah satu sekolah madrasah aliyah swasta di Kota Depok. Remaja dipilih menjadi responden karena pada masa ini terjadi pertumbuhan dan perkembangan yang sangat cepat, baik secara biologis, kognitif dan sosial-emosional yang dapat berpengaruh pada kesehatan. ${ }^{1}$ Selain itu, pada usia remaja memiliki kemampuan untuk memahami informasi yang rumit dan pada masa remaja ini memiliki daya tangkap dan pola pikir yang baik ${ }^{11}$. Hal ini sejalan dengan teori dari Notoatmodjo, bahwa umur dapat berpengaruh terhadap daya tanggap dan cara pikir seseorang terhadap informasi. Semakin bertambah usia seorang anak maka semakin bertambah daya tangkap dan pola pikirnya ${ }^{12}$. Berdasarkan hasil penelitian, usia responden berada pada rentang usia 14-19 tahun dan mayoritas responden berada pada rata-rata usia 16-17 tahun sehingga pada usia ini remaja dinilai mampu menerima informasi mengenai COVID-19 dengan baik serta diharapkan pengetahuan mengenai COVID-19 dapat diterapkan pada kehidupan remaja sebagai upaya untuk mencegah terjadi penyebaran virus COVID-19 yang semakin meluas.

Jenis kelamin merupakan salah satu faktor internal yang dapat mempengaruhi pertumbuhan dan perkembangan pada usia remaja, khususnya pada perkembangan kognitif yang berhubungan dengan proses berpikir ${ }^{13}$. Hal ini dikarenakan pertumbuhan otak perempuan meningkat 1 tahun lebih cepat daripada laki-laki yaitu pada usia 11 tahun, sedangkan pertumbuhan otak laki-laki meningkat $2 x$ lebih cepat dari pada perempuan dalam usia 15 tahun, sehingga akan mempengaruhi bagaimana cara berpikir dan mengolah informasi pada remaja ${ }^{14}$. Berdasarkan hasil penelitian didapatkan bahwa siswi berjenis kelamin perempuan lebih banyak dibandingkan dengan siswa berjenis kelamin laki-laki.

\section{Tingkat Pengetahuan Responden tentang COVID-19}

Berdasarkan hasil penelitian, dapat dilihat bahwa sebelum dilakukan pendidikan kesehatan proporsi frekuensi siswa-siswi dengan pengetahuan kurang cukup tinggi. Hal ini menunjukan bahwa siswa-siswi Madrasah Aliyah Nurul Huda masih memiliki pengetahuan rendah mengenai COVID-19.

Pengetahuan merupakan hasil dari tahu yang dapat terjadi setelah individu melakukan penginderaan terhadap suatu obyek tertentu ${ }^{15}$. Pengetahuan atau kognitif adalah domain yang memiliki peran penting dalam membentuk perilaku seseorang. Tindakan yang terwujud pada seseorang dapat disebabkan oleh pengetahuan yang dimilikinya. Suatu informasi yang diberikan pada individu akan memiliki pengaruh pada pengetahuannya. Walaupun tingkat pendidikan yang dimiliki seseorang rendah namun apabila memperoleh informasi yang baik maka akan terjadinya peningkatan pengetahuan pada dirinya ${ }^{3}$.

Berdasarkan hasil penelitian, pengetahuan remaja mengenai COVID-19 sebelum dilakukan pendidikan kesehatan menunjukkan bahwa kategori kurang cukup tinggi, dibandingkan dengan kategori cukup dan baik dan sesudah dilakukan pendidikan kesehatan dengan media audio-visual berupa video, menunjukkan bahwa kategori kurang 
dan kategori cukup menurun, sedangkan kategori baik meningkat. Hal ini menunjukan bahwa terjadi peningkatan pengetahuan sesudah dilakukan pendidikan kesehatan melalui media audio-visual berupa video. Hasil ini sejalan dengan penelitian yang dilakukan oleh Fadilah, dkk pada tahun 2020 menunjukkan bahwa terdapat perbedaan yang signifikan terhadap pengetahuan dalam meningkatkan imunitas untuk menghadapi COVID-19 sebelum dan sesudah diberikannya pendidikan kesehatan melalui seminar online ${ }^{17}$.

Pengetahuan mengenai COVID-19 dalam penelitian ini mencangkup pengertian COVID-19, tanda dan gejala, penyebab COVID-19, cara penularannya, cara pencegahannya, dan penanggulangan bila terkena COVID-19, sehingga dengan dilakukannya penyuluhan kesehatandiharapkan hal ini dapat membantu remaja dalam meningkatkan pengetahuan mengenai COVID19. Pengetahuan dibagi menjadi 6 tingkatan pada penelitian ini pengetahuan pada siswa tentang COVID-19 masih sampai tahap pertama yaitu tahu (know). Hal ini terlihat dari kemampuan siswa dalam menjawab soal tentang COVID-19 yang diberikan oleh peneliti.

Pengaruh Penyuluhan Kesehatan tentang COVID-19 Melalui Media Audio-Visual terhadap Pengetahuan Remaja

Berdasarkan hasil penelitian, menunjukan bahwa rata-rata tingkat pengetahuan sebelum diberikan pendidikan kesehatan berada dalam kategori kurang. Kurang nya pengetahuan remaja mengenai COVID-19 ini disebabkan karena remaja tidak pernah mencari tahu dan tidak pernah mendapatkan informasi tersebut sebelumnya. Namun, setelah diberikan promosi kesehatan, rata-rata tingkat pengetahuan meningkat menjadi berada dalam kategori baik. Hasil ini sejalan dengan penelitian yang dilakukan oleh Jaji pada tahun 2020, bahwa pendidikan mengenai COVID-19 berpengaruh terhadap peningkatan pengetahuan hal ini dilihat dari perbedaan yang signifikan antara pengetahuan sebelum dan sesudah diberikan pendidikan kesehatan $^{18}$.

Peningkatan pengetahuan ini terjadi karena pendidikan kesehatan merupakan proses pendidikan untuk memperoleh sesuatu yang baru dan untuk diketahui serta dimengerti ${ }^{19}$. Sejalan dengan upaya pemerintah dalam meningkatan pengetahuan masyarakat, pemerintah melakukan upaya/program berupa Strategi Komunikasi Perubahan Perilaku (KPP) dalam Pencegahan COVID-19 melalui promosi kesehatan yaitu pendidikan kesehatan yang bertujuan untuk mempercepat peningkatan pengetahuan masyarakat termasuk remaja untuk dapat mencegah terjadinya resiko dan dampak buruk dari masalah kesehatan yang sehingga mereka dapat mengambil langkah dan tindakan cepat dan tepat sehingga dapat melindungi diri dan menghindari mereka dari wabah COVID-1920. Hal ini sejalan dengan penelitian yang dilakukan Habaehan pada tahun 2009 (dalam Adliyani) membuktikan bahwa pengetahuan yang baik mengenai suatu penyakit akan ikut mempengaruhi kondisi kesehatan seseorang menjadi baik pula ${ }^{14}$.

Penggunaan media dalam pendidikan kesehatan sangat membantu dalam meningkatkan pengetahuan seseorang. Terjadinya peningkatan pengetahuan yang signifikan disebabkan karena siswa mendapatkan informasi baru mengenai COVID-19 dan media yang digunakan dalam penyuluhan kesehatan dalam menyampaikan informasi dapat mempengaruhi peningkatan pengetahuan $^{3}$.

Pada penyuluhan kesehatan yang dilakukan pada hari Senin, tanggal 04 Januari 2021 melalui media audio-visual yaitu video kepada 60 responden, hal ini berarti menggunakan dua indera yaitu mata dan telinga sehingga informasi dan pengetahuan yang diperoleh lebih muda dan jelas untuk diterima. Alat indera pada manusia merupakan faktor yang memiliki peranan penting dalam proses penerimaan informasi ${ }^{21}$. Dengan kata lain alat peraga ini dimaksudkan untuk mengarahkan indera sebanyak mungkin kepada suatu objek atau pesan, sehingga mempermudah pemahaman tentang COVID19. ${ }^{15}$ Hal ini sejalan dengan penelitian yang dilakukan oleh Desi Natalia Nadeak, dkk pada tahun 2013 menunjukkan bahwa pendidikan kesehatan dengan memakai media audio-visual sangat efektif dalam membantu terjadinya peningkatan pengetahuan pada individu ${ }^{22}$.

\section{KESIMPULAN DAN SARAN}

Adanya peningkatan pengetahuan
remaja sesudah diberikan pendidikan
kesehatan tentang COVID-19 melalui media
audio-visual berupa video dengan rata-rata
12,52 menjadi 20,97. Serta ada pengaruh


pendidikan kesehatan tentang COVID-19 melalui media audio-visual terhadap pengetahuan remaja di Madrasah Aliyah Nurul Huda Kota Depok dengan p-value sebesar 0,001 .

Bagi Responden diharapkan responden dapat mencari informasi mengenai COVID-19 dari berbagai sumber yang dapat diakses dengan mudah dan remaja memiliki kemauan untuk memahami lebih dalam mengenai COVID-19 agar remaja dapat melakukan upaya pencegahan penyebaran COVID-19 dengan baik sehingga membantu menurunkan angka kejadian COVID-19 di Indonesia. Selain itu, bagi peneliti selanjutnya diharapkan dapat melakukan penelitian mengenai COVID-19 dengan metode lain seperti metode peer education atau metode massa yang mudah diterima oleh responden dan terdapat kelompok kontrol.

\section{DAFTAR PUSTAKA}

1. WHO. Recognizing adolescence, Adolescence: A Period Needing Special Attention. 2014; Available from: http://apps.who.int/adolescent/secondde cade/section2/ \%0Apage1/recognizingadolescence.html

2. Winarti A, Fatimah FS, Rizky W. Pengaruh Pendidikan Kesehatan Terhadap Kecemasan Tentang Menarche pada Siswi Kelas V Sekolah Dasar. J Ners Dan Kebidanan Indones 5(1), 51 [Internet]. 2017; Available from:

https://doi.org/10.21927/jnki.2017.5(1). 51-57.

3. Notoatmodjo S. Ilmu Perilaku Kesehatan. Jakarta: Rineka Cipta. 2010.

4. Kementerian Kesehatan RI. Pedoman Pencegahan dan Pengendalian Coronavirus Disease (COVID-19). 2020.

5. Tim Satuan Tugas Penanganan COVID-19. Peta Resiko. 2020; Available from: https://covid19.go.id/

6. Antara, Rini. Mayoritas Pelanggar Protokol Kesehatan di Yogyakarta Bukan Wisatawan [Internet]. 2020 [cited 2020 Oct 21]. Available from: https://travel.tempo.co/read/1382893/m ayoritas-pelanggar-protokol-kesehatandi-yogyakarta-bukanwisatawan/full\&view $=$ ok

7. Buana DR. Analisis Perilaku
Masyarakat Indonesia dalam Menghadapi Pandemi Virus Corona (Covid-19) dan Kiat Menjaga Kesejahteraan Jiwa. SALAM J Sos dan Budaya Syar-i. 2020;7(3).

8. Mubarak I. Ilmu Kesehatan Masyarakat. Jakarta: Salemba Medika. 2012.

9. Habibie N. UNICEF Survei 4.000 Remaja Terkait Covid-19, 70 Persen Percaya Langkah Pemerintah. 2020; Available from: https://www.merdeka.com/peristiwa/un icef-survei-4000-remaja-terkait-covid19-70-persenpercaya-langkahpemerintah.html\%0A

10. Maulana, H, D J. Promosi Kesehatan, Jakarta: Buku Kedokteran EGC. 2009.

11. Herlina. Bibliotherapy: Mengatasi Masalah Anak dan Remaja Melalui Buku. Pustaka Cendekia Utama, Bandung. 2013.

12. Budiman, Riyanto A. Kapita Selekta Quesioner: Pengetahuan dan Sikap dalam Penelitian Kesehatan. Jakarta: Salemba Medika. 2014.

13. Abrori. Di Simpang Jalan Aborsi: Sebuah Studi Kasus Terhadap Remaja yang Mengalami Kehamilan Tak Diinginkan. Gigih Pustaka Mandiri : Yogyakarta. [Internet]. 2014. Available from:

https://books.google.co.id/books?id=Z $\mathrm{X} 5 \mathrm{fDw}$

AAQBAJ\&p $\% 0 \mathrm{Ag}=\mathrm{PA} 19 \& \mathrm{dq}=$ perilak $\mathrm{u}+$ tertutup\&hl $=\mathrm{id} \& \mathrm{sa}=\mathrm{X} \& \mathrm{ved}=0 \mathrm{ahUK}$ Ewjpjb57PfgAh\%0AX17nMBHTf1CX

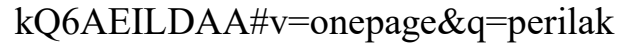
$\mathrm{u}$ tert utup\& $\mathrm{f}=$ false

14. Adliyani ZON, Angraini DI, Soleha TU. Pengaruh Pengetahuan, Pendidikan dan Ekonomi terhadap Perilaku Hidup Bersih dan Sehat pada Masyarakat Desa Pekonmon Kecamatan Ngambur Kabupaten Pesisir Barat. Major J. 2017;7(1):6-13.

15. Notoatmodjo S. Promosi Kesehatan dan Perilaku Kesehatan. Rineka Cipta : Jakarta. 2012.

16. Arikunto S. Prosedur Penelitian Suatu Pendekatan Praktik, Rineka Cipta, Jakarta. 2010.

17. Fadilah $\mathrm{M}$, Indah $\mathrm{W}$, Ningsih $\mathrm{F}$, Berlin $\mathrm{O}$, Wimaulia A, Syakurah RA. Pengaruh Seminar Online Terhadap Pengetahuan Dalam Meningkatkan 
Imunitas Untuk Menghadapi COVID19 Dan Persepsi Mengenai New Normal Pada Masyarakat Awam. J Kesehat Masy. 2020;6(2):134-49.

18. Jaji. Pengaruh pendidikan kesehatan dengan media leaflet terhadap pengetahuan warga dalam pencegahan penularan covid 19. Proceeding Semin Nas Keperawatan 2020 [Internet]. 2020;(1):135-9. Available from: http://conference.unsri.ac.id/index.php/ SNK/article/view/1764

19. Fatimaah AS. Efektivitas Penyuluhan Gizi Menggunakan Media PGS CARDS Dibandingkan Leaflet Terhadap Peningkatan Pengetahuan Pedoman Gizi Seimbang Pada Siswa SekolahDasar [Internet]. 2017 [cited 2021 Jan 6]. Available from: http://eprints.poltekkesjogja.ac.id/617/1 /naskah publikasi.pdf
20. Kementerian Kesehatan RI. Strategi Komunikasi Perubahan Perilaku (KPP) Dalam Pencegahan Covid-19. 2020;148.

21. Supratman LPS, Mahadian AB. Psikologi Komunikasi [Internet]. 1st ed. Penerbit Deepublish; 2018 [cited 2021 Jan 30]. Available from: https://books.google.co.id/books?id=h2 ZmDwAAQBAJ\&printsec $=$ frontcover $\& \mathrm{hl}=\mathrm{id} \# \mathrm{v}=$ onepage $\& \mathrm{q} \& \mathrm{f}=$ false

22. Nadeak DN, Agrina, Misrawati. Efektifitas Promosi Kesehatan Melalui Media Audiovisual Mengenai HIV/AIDS Terhadap Peningkatan Pengetahuan Remaja Tentang HIV/AIDS. J Online Mhs Bid Ilmu Keperawatan [Internet]. 2014 Feb 28 [cited 2021 Jan 7];1(1):1-8. Available from:

https://jom.unri.ac.id/index.php/JOMPS IK/article/view/3509 